\author{
Asian Development Policy Review \\ $\operatorname{ISSN}(e): \quad 2313-8343$ \\ $\operatorname{ISSN}(p): \quad 2518-2544$ \\ DOI: $10.184 .88 /$ journal.107.2018.62.70.76 \\ Vol. 6, No. 2, 70-76 \\ (C) 2018 AESS Publications. All Rights Reserved. \\ URL: www.aessweb.com
}

\title{
THE DIFFERENCE OF OUTWARD-ORIENTED ECONOMY IN SIX PROVINCES OF CENTRAL CHINA BASED ON THE THEIL INDEX
}

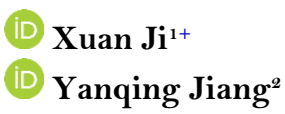

Xuan Ji ${ }^{1+}$

Yanqing Jiang ${ }^{2}$

\author{
${ }^{1,2}$ School of Economics and Finance, Shanghai International Studies \\ University, Shanghai, China \\ ${ }^{2}$ Email:992181258@qq.com Tel:+862167701319 \\ 2Email:yjiang@shisu.edu.cn Tel:+862167701054
}

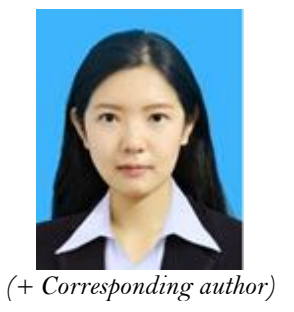

ABSTRACT

Six provinces in the central part of China are the important economic hinterland of our country. With the first development of the eastern coastal areas and the strategy of developing the West and revitalizing the northeast, the central area's economy has gradually collapsed and the outward oriented economy has also collapsed. In this paper, we use modified Theil index to analysis the degree of the outward-oriented economy difference in six provinces and the difference between inter regional and extra regional differences of total export-import volume and actual utilization of foreign capital. It is concluded that the difference of outward-oriented economy in these six provinces of central China is obvious, but the overall difference is getting smaller and the difference of the actual utilization of foreign capital is greater than the difference of total import and export volume. Inter and extra differences play a different role in Theil index of total import and export volume and actual utilization of foreign capital. By analyzing reasons of these differences, we list some suggestions about increasing Anhui province's competition of Outward-oriented economy. Each government is supposed to make full use of the policies, strengthen cooperation, conduct resources consolidation better, build more inland-ports, make full use of the advantages of labor and resources, focus on talent cultivation and exchange.

Contribution/ Originality: This study originates new formula -Theil index to analysis the degree of the outward-oriented economy difference in six provinces and the difference between inter regional and extra regional differences of total export-import volume and FDI.

\section{INTRODUCTION}

Under the background of rapid economic globalization, especially after China's accession to the World Trade Organization, China's outward-oriented economy develops rapidly. But the regional development is unbalanced under the overall rapid development pattern and the six provinces in central china have disadvantageous positions in the development process. Therefore, solving the problem of uneven development in this region is very important for improving the level of outward-oriented economy in China.

In Eaton and Tamura (1994) they develop a simple model of the choice between exploiting a technology in another country via export and via direct foreign investment. Taking population, per capita income, factor endowments, and distance into account, they find Japan to be more open to U.S. exports than any region in the 
world except East Asia (Eaton and Tamura, 1994). Cai et al. (2002) find out that there is an evidence of conditional convergence in China's growth, namely, per capita GDP in the initiative year is negatively related to growth rates in following years (Cai et al., 2002). In Zhang et al. (2013) paper, it applies cluster analysis and Theil index to inspect the regional disparity and dynamic evolution of outward-oriented economy development in Anhui Province. .It should be taken effective measures to promote outward-oriented economy harmoniously develop (Zhang et al., 2013).

$\mathrm{Z} \mathrm{Xu} \mathrm{concluded} \mathrm{that} \mathrm{the} \mathrm{extent} \mathrm{of} \mathrm{economic} \mathrm{opening} \mathrm{determines} \mathrm{the} \mathrm{development} \mathrm{status} \mathrm{of} \mathrm{outward-oriented}$ economy. It is necessary to make a breakthrough in foreign investment and foreign trade, two key factors measuring the level of open economy (Xu, 2006).

Scholars have studied about outward-oriented economic differences between their own provinces (Chen, 2004) or the traditional central and west area in the past. There were few studies on the difference among the six provinces in the central China and the specific reasons for the differences. In studies of the current outward-oriented economic development of these provinces, some details were not involved. We found a lot of problems need to be solved. Therefore, this paper analyzes the problems of outward-oriented economic development in six provinces and gives some suggestions on the outward-oriented economy of Anhui province.

\section{ANALYSIS ON THE DIFFERENCE OF OUTWARD-ORIENTED ECONOMY IN SIX PROVINCES OF CENTRAL CHINA}

\subsection{Selection of Evaluation Index for Outward-Oriented Economic Development}

There are many indicators to measure the development of outward-oriented economy in a region, which can be considered from the aspects of horizontal scale speed and so on, in particular, total import and export volume, foreign investment, attracting foreign capital and international financial cooperation, international labor service cooperation, foreign tourism development degree and so on. Bryant and Javalgi (2014) from many indicators, we often use the total export-import volume, the actual use of foreign capital to measure the scale of outward-oriented economy development in the academic research. Use the degree of dependence on exports, dependence on import and dependence on foreign investment to measure the level of export-oriented economy development; Use the average annual compound growth rate of foreign capital as the index to measure the development speed of outwardoriented economy; Use the contribution rate of foreign trade to economic growth, the pulling degree, the contribution rate of foreign capital to economic growth, and the pulling degree as the index to measure the influence of outward-oriented economy.

From the national existing economic and financial policies, the stability of data collection, sustainable observation and the degree of reflection on the development of outward-oriented economy, this paper chooses the total export-import volume and the actual use of foreign capital (FDI) (Keho, 2012) two indicators as the weight to reflect the difference between the total export-import volume and the actual utilization of foreign capital's influence on the outward-oriented economic development of central six provinces.

\subsection{Data Description and Calculation Method}

The Theil index, known as the Thiel Entropy standard (Theil's entropy measure), is used by Thiel to calculate income inequality by using the entropy concept in information theory. It is an index of income and economic development disparity (or inequality) between individuals or regions. Theil index (T) is composed of regional difference $(\mathrm{Tw})$ and interval difference $(\mathrm{Tb})$, which can be used to analyze the contribution degree of regional difference and interval difference to the total difference. The greater the value of Theil, the greater the imbalance of the regional economic indicators.

According to the research needs of this paper, the Theil index is used to analyze the difference of outwardoriented economy in six provinces of central China, which can be defined as 


$$
T=\sum_{i} \sum_{j}\left(\frac{A i j}{A}\right) \ln \left(\frac{A i j / A}{B i j / B}\right)
$$

Define the regional difference $\mathrm{Tc}$ and interval differences $\mathrm{Tb}$ in area i:

$$
\begin{gathered}
T c=\sum_{j} \frac{A i j}{A i} \ln \left(\frac{A i j / A i}{B i j / B i}\right) \\
T b=\sum_{\mathrm{i}} \frac{A i}{A} \ln \left(\frac{A i}{A} / \frac{B i}{B}\right)
\end{gathered}
$$

Aij is an outward-oriented economic index of $\mathrm{j}$ city in i province, $\mathrm{Ai}$ is the index of $\mathrm{i}$ province, $\mathrm{A}$ is the index value of total six province; $\mathrm{Bij}$ is the GDP of $\mathrm{j}$ city in i province, $\mathrm{Bi}$ is the index of i province, $\mathrm{B}$ is the index value of six province. The outward-oriented economic Theil index of six province can be decomposed into interval difference and regional difference, which is expressed as

$$
T=T w+T b=\sum_{i} \frac{A i}{A} T c+T b
$$

This paper selects the total import and export volume and FDI as indicators. Because the calculation process involves taking logarithm, there will be positive and negative cancellation. In order to reduce the error, the original formula will be modified to

$$
T=\sum_{i} \sum_{j}\left(\frac{A i j}{A}\right)\left|\ln \left(\frac{A i j / A}{B i j / B}\right)\right|
$$

We bring the total export-import volume and FDI of six provinces in central china (Hubei, Hunan, Henan, Anhui, Jiangxi, Shanxi) and different cities in six provinces (excluding the minority autonomous regions) into the revised formula to get the calculation results.

\section{COMPUTATIONAL RESULTS AND DATA ANALYSIS}

2.1. Computational Results

2.1.1. Analysis on the Difference of Total Import and Export Volume in Six Provinces

Table-1. Theil index of total imports and exports of six provinces 2005-2015

\begin{tabular}{l|l|l|l}
\hline year & regional difference $(\mathbf{T w})$ & interval difference $(\mathbf{T b})$ & $\mathbf{T}=\mathbf{T w}+\mathbf{T b}$ \\
\hline 2005 & 0.6162 & 0.3192 & 0.9353 \\
\hline 2006 & 0.6233 & 0.3138 & 0.9371 \\
\hline 2007 & 0.6172 & 0.3629 & 0.9800 \\
\hline 2008 & 0.6044 & 0.3836 & 0.9880 \\
\hline 2009 & 0.6143 & 0.4001 & 1.0144 \\
\hline 2010 & 0.6243 & 0.3811 & 1.0054 \\
\hline 2011 & 0.6387 & 0.3761 & 1.0149 \\
\hline 2012 & 0.6271 & 0.4283 & 1.0554 \\
\hline 2013 & 0.5911 & 0.3309 & 0.9220 \\
\hline 2014 & 0.5821 & 0.2588 & 0.8409 \\
\hline 2015 & 0.6032 & 0.2903 & 0.8935 \\
\hline
\end{tabular}

From table 1, it can be seen that the Theil index of total export-import volume of six provinces in 10 years floats around 1, thus we can say the regional difference of total import and export is great. Starting from 2013, the 
Theil index begins to fall, reaching its lowest level in 2014, but is also at high levels. It is in a downward trend at an overall look, especially in the last three years. The comparison between these two parts can be seen that the regional difference is far greater than the interval difference. Theil index of the total export-import volume is mainly contributed by regional differences. The overall change trend of regional difference、 interval difference and total difference is same.

\subsubsection{Analysis of the Difference of FDI in Six Provinces}

Table-2. 2005-2015 Theil index of FDI

\begin{tabular}{l|l|l|l}
\hline year & regional difference $(\mathbf{T w})$ & interval difference $(\mathbf{T b})$ & $\mathbf{T}=\mathbf{T w}+\mathbf{T b}$ \\
\hline 2005 & 0.5052 & 0.8291 & 1.3343 \\
\hline 2006 & 0.4540 & 0.7680 & 1.2221 \\
\hline 2007 & 0.4372 & 0.7182 & 1.1554 \\
\hline 2008 & 0.4208 & 0.6497 & 1.0705 \\
\hline 2009 & 0.4392 & 0.7598 & 1.1989 \\
\hline 2010 & 0.4357 & 0.6640 & 1.0997 \\
\hline 2011 & 0.4772 & 0.8011 & 1.2784 \\
\hline 2012 & 0.4549 & 0.7604 & 1.2153 \\
\hline 2013 & 0.3917 & 0.6290 & 1.0207 \\
\hline 2014 & 0.3540 & 0.3997 & 0.7538 \\
\hline
\end{tabular}

It is shown from table 2 that the Theil index of FDI is in the downward trend and the difference of FDI in six provinces is generally reduced. Comparing the regional difference with the interval difference, we can conclude that the interval difference is obviously greater than the regional difference, the difference among the six provinces is greater than the difference in each province and the contribution degree of the whole difference is higher.

\subsubsection{Comparative Analysis of the Difference between Total Export-Import Volume and FDI in Six} Provinces

Table-3. 2005-2015 Difference of Theil index of total export-import volume and the FDI in six provinces

\begin{tabular}{|c|c|c|c|c|c|c|}
\hline \multirow{2}{*}{ Year } & \multicolumn{3}{|c|}{ Total export-import volume } & \multicolumn{3}{|l|}{ FDI } \\
\hline & Tw & $\mathbf{T b}$ & $\mathbf{T}=\mathbf{T w}+\mathbf{T b}$ & Tw & $\mathbf{T b}$ & $\mathbf{T}=\mathbf{T w}+\mathbf{T b}$ \\
\hline 2005 & 0.6162 & 0.3192 & 0.9353 & 0.5052 & 0.8291 & 1.3343 \\
\hline 2006 & 0.6233 & 0.3138 & 0.9371 & 0.4540 & 0.7680 & 1.2221 \\
\hline 2007 & 0.6172 & 0.3629 & 0.9800 & 0.4372 & 0.7182 & 1.1554 \\
\hline 2008 & 0.6044 & 0.3836 & 0.9880 & 0.4208 & 0.6497 & 1.0705 \\
\hline 2009 & 0.6143 & 0.4001 & 1.0144 & 0.4392 & 0.7598 & 1.1989 \\
\hline 2010 & 0.6243 & 0.3811 & 1.0054 & 0.4357 & 0.6640 & 1.0997 \\
\hline 2011 & 0.6387 & 0.3761 & 1.0149 & 0.4772 & 0.8011 & 1.2784 \\
\hline 2012 & 0.6271 & 0.4283 & 1.0554 & 0.4549 & 0.7604 & 1.2153 \\
\hline 2013 & 0.5911 & 0.3309 & 0.9220 & 0.3917 & 0.6290 & 1.0207 \\
\hline 2014 & 0.5821 & 0.2588 & 0.8409 & 0.3540 & 0.3997 & 0.7538 \\
\hline 2015 & 0.6032 & 0.2903 & 0.8935 & 0.3622 & 0.4010 & 0.7632 \\
\hline
\end{tabular}

The comparison can be seen that the Theil index of FDI is greater than the total export-import volume's. That means the difference of FDI is greater. Outward-oriented economy differences are mainly caused by the actual utilization of foreign capital. The regional difference between the total export-import volume is greater than that of FDI, and the interval difference between FDI is far greater than the total amount of imports and exports of the 
interval difference. It can be seen that the religion difference of the total export-import volume and the interval difference of FDI are the main reasons for the outward-oriented economy difference in six provinces.

2.1.4. Analysis of the Interval Contribution Rate in the Difference Zone between the Total Import and Export of Six Provinces and the Actual Utilization of Foreign Capital

Table-4. 2005-2015 The different contribution rate to the inter-export economy in central six province

\begin{tabular}{|c|c|c|c|c|c|c|}
\hline \multirow[b]{2}{*}{ year } & \multicolumn{3}{|c|}{ Total export-import volume } & \multicolumn{3}{|l|}{ FDI } \\
\hline & $\mathbf{T}=\mathbf{T w}+\mathbf{T b}$ & $\begin{array}{l}\text { Contribution } \\
\text { rate of region } \\
\text { difference }\end{array}$ & $\begin{array}{l}\text { Contribution } \\
\text { rate of interval } \\
\text { difference }\end{array}$ & $\mathbf{T}=\mathbf{T w}+\mathbf{T b}$ & $\begin{array}{l}\text { Contribution } \\
\text { rate of region } \\
\text { difference }\end{array}$ & $\begin{array}{l}\text { Contribution } \\
\text { rate of interval } \\
\text { difference }\end{array}$ \\
\hline 2005 & 0.9353 & $65.88 \%$ & $34.12 \%$ & 1.3343 & $37.86 \%$ & $62.14 \%$ \\
\hline 2006 & 0.9371 & $66.51 \%$ & $33.49 \%$ & 1.2221 & $37.15 \%$ & $62.85 \%$ \\
\hline 2007 & 0.9800 & $62.98 \%$ & $37.02 \%$ & 1.1554 & $37.84 \%$ & $62.16 \%$ \\
\hline 2008 & 0.9880 & $61.17 \%$ & $38.83 \%$ & 1.0705 & $39.31 \%$ & $60.69 \%$ \\
\hline 2009 & 1.0144 & $60.56 \%$ & $39.44 \%$ & 1.1989 & $36.63 \%$ & $63.37 \%$ \\
\hline 2010 & 1.0054 & $62.09 \%$ & $37.91 \%$ & 1.0997 & $39.62 \%$ & $60.38 \%$ \\
\hline 2011 & 1.0149 & $62.94 \%$ & $37.06 \%$ & 1.2784 & $37.33 \%$ & $62.67 \%$ \\
\hline 2012 & 1.0554 & $59.42 \%$ & $40.58 \%$ & 1.2153 & $37.43 \%$ & $62.57 \%$ \\
\hline 2013 & 0.9220 & $64.11 \%$ & $35.89 \%$ & 1.0207 & $38.37 \%$ & $61.63 \%$ \\
\hline 2014 & 0.8409 & $69.23 \%$ & $30.77 \%$ & 0.7538 & $46.97 \%$ & $53.03 \%$ \\
\hline 2015 & 0.8935 & $67.51 \%$ & $32.49 \%$ & 0.7632 & $47.45 \%$ & $52.55 \%$ \\
\hline
\end{tabular}

It can be seen that the difference of total export-import volume in different provinces is the main reason for the difference of import and export in central China. From Analysis of the difference of FDI, interval difference is higher than the regional difference, Interval difference is the main reason for the difference of FDI in the central area, the overall trend of this gap is steady even decline, the biggest difference happens in 2009

\subsection{Conclusion of the Analysis of Theil Index}

\subsubsection{The Outward-Oriented Economic Development of Six Provinces in Central China Has Obvious} Differences

The Theil index calculated from the total import and export volume and the actual amount of foreign investment in the past 2005-2015 years shows that the average value of import and export volume has reached 0.96 over the past eleven years, and the actual utilization of foreign capital has reached a high value of 1.10. The Theil index reaches 0.5 , which means that the difference is obvious. We can see that the difference between the six provinces' outward-oriented economy development level is huge, and the development of each province is out of line, especially in the actual utilization of foreign investment.

\subsubsection{The Difference of the Development of Outward-Oriented Economy in Six Provinces is Smaller}

The Theil index is declining as a whole, and there is a fluctuation in the middle due to the external factors such as the financial crisis in 2008. In 2015, the Theil index of import and export decreased by 0.07 compared with the eleven year average. The Theil index of actual utilization of foreign capital decreases by 0.34 over the ten years, and the decline is more obvious. The difference between the two regions is in the same direction with the overall difference, which is also a downward trend in the past eleven years, especially the interval difference of the actual utilization of foreign capital. The value in 2015 decreased by 0.57 compared with that in 2005. The decline is more than $50 \%$. 
2.2.3. Region and Interval Difference of Six Provinces' Outward-Oriented Economic Development are Balanced

The results from the Theil index can be seen that the contribution level of the Theil index is different when it is decomposed into regional and interval difference. The difference between different provinces is the main factor that affects the total export-import volume, and the difference of FDI is mainly caused by the difference between the provinces.

\section{SUGGESTIONS ON PROMOTING THE COORDINATION AND RAPID DEVELOPMENT OF OUTWARD-ORIENTED ECONOMY IN ANHUI PROVINCE}

Development of outward-oriented economy in six provinces have achieved fruitful results, especially in Henan province. Anhui Province is in the previous position, and is compared with Henan province and the east Coast developed areas, but it still has a larger catch-up space in the level of development.

3.1. To Optimize the Economic Environment of the Province with the Development of the Central China's New Decade

As the continuation of the old strategy "The rise of the middle part", the state put forward the strategy "the rise of the middle part in the new decade" in 2016 and continued to support the central area development strategically. Anhui should rely on the new strategy, which is on the basis of the new land space development pattern. It formats a new all-round opening-up strategy. Under the state support policy and self-optimizing development, we should improve the economic environment of our province and develop the open economy fully (Lee, 2014).

\subsection{Develop Inland Port and Speed up the Construction of Inland Self-Trade Area}

We need to speed up the construction of highway and railway routes, make more cities and counties into the traffic construction consideration, Chen et al. (2011) and have reasonable plans in order to make three kinds of transportation seamless docking, Tang and University (2017) to speed up the logistics development, reduce the natural condition to bring the disadvantage, enhance the regional economic attraction (Urpelainen, 2011).

\subsection{Increase the Cooperation in the Development of Outward-Oriented Economy in Different Cities}

All cities should increase their economic cooperation, and make effective use of technology, resources and market through measures such as entrepreneurs' annual meeting, trade association and outward-oriented economic talents exchange. Stucchi et al. (2015) the establishment of intern regional coordination, cooperation institutions and mechanisms should be carried out according to the current situation of resources in different cities and municipalities. Léon et al. (2010) we should rationally undertake investment and industrial transfer from inside and outside the province and make full use of foreign capital to maximize the utility (Stucchi et al., 2015).

\section{CONCLUSION}

Summing up the full text, the development of the outward-oriented economy in the six provinces in Central China has a large difference based on the results of the Theil index. The Theil index, calculated by the total import and export total and the foreign direct investment (FDI), is more than 0.5, what is the obvious difference value. In particular, the actual utilization of foreign investment is more than 1 , but the trend of the difference of six provinces' outward-oriented economy development is decreasing. The contribution of interval and regional difference to the overall difference is relatively balanced. We should decrease the development gap between the six provinces and promote the rapid and coordinated development of the six provinces' outward-oriented economy by 
some kinds of practical means. Under the background of the new era, the six provinces' pace of opening up will be more and more fast.

Funding: This study received no specific financial support.

Competing Interests: The authors declare that they have no competing interests.

Contributors/Acknowledgement: Both authors contributed equally to the conception and design of the study.

\section{REFERENCES}

Bryant, C.E. and R.G. Javalgi, 2014. Global economic integration in developing countries: The role of corruption and human capital investment. Journal of Business Ethics, 136(3): 1-14. View at Publisher

Cai, F., D. Wang and Y. Du, 2002. Regional disparity and economic growth in China: The impact of labor market distortions. China Economic Review, 13(2-3): 197-2 12. View at Google Scholar | View at Publisher

Chen, H., X. Zou and Q. Chen, 2011. Export-oriented economy \& environmental pollution in China: The empirical study by simultaneous equation model. Energy Procedia, 5(3-4): 884-889. View at Google Scholar $\mid$ View at Publisher

Chen, X.M., 2004. Spatial difference of economic opening and development strategy of outward-oriented economy in Hunan province. Contemporary Finance \& Economics, 30(03): 45-53. View at Google Scholar

Eaton, J. and A. Tamura, 1994. Bilateralism and regionalism in Japanese and U.S. trade and direct foreign investment patterns. Journal of the Japanese \& International Economies, 8(4): 478-510. View at Google Scholar $\mid$ View at Publisher

Keho, Y., 2012. Does fdi contribute to the integration into the global economy? Time-series evidence for ten African countries. African Finance Journal, 14(3): 3-4. View at Google Scholar

Lee, S.W., 2014. The impact of outward-oriented economic reform on income inequality in China: 1978-2007. Urban China in the new Era. Berlin Heidelberg: Springer.

Léon, G., C. Quiroga, D. Centrón and P.H. Roy, 2010. Diversity and strength of internal outward-oriented promoters in group iic-attc introns. Nucleic Acids Research, 38(22): 8196-8207. View at Google Scholar | View at Publisher

Stucchi, T., T. Pedersen and V. Kumar, 2015. The effect of institutional evolution on Indian firms' internationalization: Disentangling inward- and outward-oriented effects. Long Range Planning, 48(5): 346-359. View at Google Scholar |View at Publisher

Tang, Z.Y. and S.N. University, 2017. The different influence of outward foreign direct investment motivation on industrial structure_a case study of Shandong and Japan 1975-1990. Special Zone Economy, 255(4): 410-425.

Urpelainen, J., 2011. Export orientation and domestic electricity generation: Effects on energy efficiency innovation in select sectors. Energy Policy, 39(9): 5638-5646. View at Google Scholar | View at Publisher

$\mathrm{Xu}$, Z., 2006. Regional difference of economic opening and development strategy of outward-oriented economy in Yunnan province. Academic Exploration, 110(2): 5-12.

Zhang, R.Q., G.H. Liu and M. Fang, 2013. Analysis of the regional disparity of outward-oriented economy development in Anhui province. East China Economic Management, 20(2): 20-25. 